\title{
Microbial Diversity in Various Combinations of Phosphorous Sources in Maize-Groundnut Cropping Sequence in an Alfisols of Odisha, India
}

\author{
Suraj Mali*, G.H. Santra, Tupaki Lokya and Jaya Prajapati \\ Department of Soil Science and Agricultural Chemistry, College of Agriculture, \\ OUAT, Bhubaneswar-751003, Odisha, India \\ *Corresponding author
}

\begin{tabular}{|c|}
\hline \\
\hline $\begin{array}{l}\text { Low grade Rock phosphate } \\
\text { (RP), Single super phosphate } \\
\text { (SSP), Lime @0.2LR, Lime } \\
\text { requirement (LR), Loamy } \\
\text { acidic soil, Maize-Groundnut } \\
\text { crop, Urea, Murate of potash } \\
\text { (MOP), Lime requirement } \\
\text { (LR), Pikovksaya medium, } \\
\text { Colony Forming Unit (c.f.u.) }\end{array}$ \\
\hline Article Info \\
\hline $\begin{array}{l}\text { Accepted: } \\
28 \text { January } 2018 \\
\text { Available Online: } \\
\text { 10 February } 2018\end{array}$ \\
\hline
\end{tabular}

A B S T R A C T
A field experiment was conducted with maize-groundnut cropping sequence. Rock phosphate and its combination with SSP were used as nutrient sources during Rabi 201617 (maize taken up in Kharif 2016). The study was carried out in the Central Farm, OUAT with the help of a field experiment laid out in Randomized Block Design with seven treatment T1 Control, T2 100\% P(RP),T3 100\% P(SSP), T4 75\% P(RP) + 25\% P(SSP), T5 $50 \% \mathrm{P}(\mathrm{RP})+50 \% \mathrm{P}(\mathrm{SSP}), \mathrm{T} 625 \% \mathrm{P}(\mathrm{RP})+75 \% \mathrm{P}(\mathrm{SSP})$ and $77100 \% \mathrm{P}(\mathrm{SSP})+$ Lime @ $0.2 \mathrm{LR}$ and replicated in thrice. The soil of the experimental field was loamy acidic (pH 5.2) having Bray's $P$ of $15.68 \mathrm{~kg} \mathrm{ha}^{-1}$. The different combinations with SSP were evaluated for their effectiveness in the cropping system. In addition to P applied @ 50kg $\mathrm{P}_{2} \mathrm{O}_{5}$ ha $^{-1}$ and $40 \mathrm{~kg} \mathrm{P}_{2} \mathrm{O}_{5}$ ha $^{-1}$ to maize and groundnut crops respectively from various sources, $\mathrm{N}$ was added @ $150 \mathrm{kgha}^{-1}$ to maize and $20 \mathrm{kgha}^{-1}$ to groundnut crop in the form of urea and $\mathrm{K} @ 50$ and $40 \mathrm{~kg} \mathrm{~K}_{2} \mathrm{O} \mathrm{ha}{ }^{-1}$ was added to maize and groundnut crop in the form of MOP. Highest maize grain yield $\left(5.03 \mathrm{t} \mathrm{ha}^{-1}\right)$ was produced due to addition of $100 \% \mathrm{P}$ (SSP) +Lime @ 0.2LR and highest pod yield $\left(2.77 \mathrm{t} \mathrm{ha}^{-1}\right)$ of groundnut was also due to $100 \% \mathrm{P}$ (SSP)+Lime@0.2LR. The total heterotrophic bacteria population (c.f.u. X $10^{4} \mathrm{~g}^{-1}$ soil)was the highest in 100\%P (SSP) + Lime@0.2LR in all the growth stage except flowering. Phosphorus solubilising bacteria population (c.f.u. $\mathrm{X} 10^{4} \mathrm{~g}^{-1}$ soil) were maximum at pod formation stage in $100 \% \mathrm{P}(\mathrm{SSP})+\mathrm{Lime} @ 0.2 \mathrm{LR}$ and $100 \% \mathrm{P}(\mathrm{RP})$ treatment but at harvest the treatment received 100\% $\mathrm{P}(\mathrm{SSP})+$ Lime @0.2LR had the highest population.

\section{Introduction}

Phosphorus is regarded as the master "key" element in crop production because of its pivotal role in the normal growth and establishment of root system, Seed formation and harvesting of the crop maturity besides being an essential constituent of nucleic acids (Mangel and Kirkby, 1987). Phosphorus is one of the most essential major growth-limiting plant nutrient which affect the overall growth of plants (Wang et al., 2009) ${ }^{[2]}$ by influencing various key metabolic processes such as cell division and development, macromolecular biosynthesis, photosynthesis and respiration of plants (Shenoy and Kalagudi, 2005; Ahemad, 2009; Ahemad, 2012; Khan, 2009; Khan, 2013). The maximum part of soil 
phosphorous, approximately $95-99 \%$ is present in the form of insoluble phosphates and hence it cannot be easily utilized by the plants (Kannapiran and SriRamkumar, 2011). Phosphorus is play an important role of biochemical storage and transfer of energy, cell elongation, root development, plant growth and several other processes in the living plant. Insoluble phosphate compounds like Rock phosphate can be solubilized by phosphatise enzymes produced by microorganisms in soil.

Insoluble phosphorous is solubilized by a major group of soil micro flora was reported and these complexes enabling plants to easily absorb phosphorous. Several reports have examined the ability of different bacterial species to solubilise insoluble inorganic phosphate compounds, such as tricalcium phosphate, dicalcium phosphate, hydroxyapatite, and rock phosphate.

Phosphorus is considered as a limiting factor in plant nutrition due to the deficiency of available soluble phosphate in the soil. However, phosphobacterium, a phosphate solubilizing bacteria able to convert the unavailable phosphate present in the soil to an available form.

The use of phosphate solubilizing bacteria as inoculants simultaneously increase $\mathrm{P}$ uptake by plants (Rodriquez and Fraga, 1999), improve nodulation and hence increase symbiotic nitrogen fixation (Dametario et al., 1972).

The effectiveness of rock phosphate of low reactivity can also be increased by application of rock phosphate to green manure crop preceding the main crop, inoculation of the field following rock phosphate application with either phosphate solubilizing microorganism or mycorrhiza (Misra and Pattanayak, 1997).

\section{Materials and Methods}

The experimental site is located in the Central Farm, OUAT, Bhubaneswar which lies at $85^{\circ}$ 47 ' 18" E latitude $20^{\circ} 16^{\prime} 51^{\prime \prime} \mathrm{N}$ longitudes with an elevation of 25.9 meter above mean sea level. The summer months from March to May/ June are hot and humid. The mean minimum and maximum temperature were $22.6^{\circ} \mathrm{C}$ and $32.6^{\circ} \mathrm{C}$ respectively. Temperatures drop to approximately $15^{\circ} \mathrm{C}$ during these months. The physico-chemical properties of the soil of experimental site were loamy texture with $\mathrm{pH} 5.2$ and Exchangeable $\mathrm{Ca}^{2+}$ 0.89 [cmol $\left.\left(\mathrm{p}^{+}\right) \mathrm{kg}^{-1}\right]$. The soil had the available Bray's P $15.68 \mathrm{~kg} \mathrm{ha}^{-1}$ (medium), Available Nitrogen $239 \mathrm{~kg} \mathrm{ha}{ }^{-1}$ (low), Available Potassium $150 \mathrm{~kg} \mathrm{ha}^{-1}$ (medium) and Organic carbon $3.4 \mathrm{~g} \mathrm{~kg}^{-1}$ Soil.

\section{Experimental details}

Field experimental design laid out in Randomized Block Design with seven treatment T1 Control, T2 100\% P(RP),T3 $100 \% \mathrm{P}(\mathrm{SSP}), \mathrm{T} 475 \% \mathrm{P}(\mathrm{RP})+25 \% \mathrm{P}(\mathrm{SSP})$, T5 50\% P(RP) + 50\% P(SSP), T6 25\% P(RP) $+75 \% \mathrm{P}(\mathrm{SSP})$ and $\mathrm{T} 7100 \% \mathrm{P}(\mathrm{SSP})+$ Lime @ $0.2 \mathrm{LR}$ and replicated in thrice times.

\section{Collection of soil sample}

Fresh rhizospheric soil was collected from each treatment \& replication at different growth stages to study the activity of soil microbial population (heterotrophic bacteria and Phosphorous solubulizing bacteria) by serial dilution and spread plate technique to ascertain the effect of different sources / combinations of P i.e. RP \& SSP.

\section{Methods enumeration of soil microbial population}

The soil microbial population (heterotrophic bacteria and Phosphorous Solubilizing 
bacteria) was determined by serial dilution and spread plate technique.

One (1) g of the collected soil samples were added to each of ten tubes containing $9 \mathrm{ml}$ distilled water thoroughly mixed and spread over petriplates containing Nutrient Agar medium and Pikovskaya medium for enumeration of total heterotrophic bacteria and Phosphorous Solubilizing Bacteria (PSB) population respectively.

The plates were incubated at $30^{\circ} \mathrm{C}$ for 24 hours for bacterial isolation and at $30^{\circ} \mathrm{C}$ for 48 hrs for heterotrophic bacteria and PSB population.

\section{Calculation}

No. of colony $x$ inverse of dilution taken $\mathrm{CFU} / \mathrm{ml}=$ vol. of inoculum taken

\section{Results and Discussion}

Total Heterotrophic Bacteria (c.f.u. X 10 ${ }^{4}$ $\mathrm{g}^{-1}$ soil)

It is clear that the population of heterotrophic Bacteria (c.f.u X $10^{4} \mathrm{~g}^{-1}$ soil) increased with the application of Phosphorous. It ranged from 44.0-78.67, 50.33-87.67and 54.67-76.67 (c.f.u $\mathrm{X} 10^{4} \mathrm{~g}^{-1}$ soil) at all growth stages respectively. Among the various sources $100 \%$ P (SSP) + Lime @ 0.2 LR resulted in maximum population followed by $50 \% \mathrm{P}(\mathrm{RP})$ $+50 \% \mathrm{P}(\mathrm{SSP})$ at all growth stages.

The later was in turn followed by $100 \% \mathrm{P}$ (Rock Phosphate) at all the cases. The steepness of change in the population was of the order of $100 \% \mathrm{P}(\mathrm{SSP})+$ Lime @ $0.2 \mathrm{LR}$ $>50 \% \mathrm{P}(\mathrm{RP})+50 \% \mathrm{P}(\mathrm{SSP})>100 \% \mathrm{P}$ $(\mathrm{RP})>75 \% \mathrm{P}(\mathrm{RP})+25 \% \mathrm{P}(\mathrm{SSP})>25 \% \mathrm{P}$ $(\mathrm{RP})+75 \% \mathrm{P}(\mathrm{SSP})>100 \% \mathrm{P}(\mathrm{SSP})$.
Phosphorous solubilising bacteria (PSB) (c.f.u. $X 10^{4} \mathrm{~g}^{-1}$ soil)-

It is comprehensible from that the Phosphorous Solubilising bacteria (PSB) population (c.f.u X $10^{4} \mathrm{~g}^{-1}$ soil) increased in all the treatments of applied Phosphorous. It ranged from 40.67-65.33, 44.00-75.00 and 47.33-65.33 (c.f.u. X $10^{4} \mathrm{~g}^{-1}$ soil) at all groundnut stages respectively.

The treatment $100 \%$ P (SSP) + Lime @ 0.2 LR recorded the highest followed by $100 \% \mathrm{P}$ (RP) phosphorous solubilising bacteria population at flowering and vice versa at pod formation. At groundnut harvest $100 \% \mathrm{P}$ (SSP) + Lime @ 0.2 LR recorded the highest followed by $75 \% \mathrm{P}(\mathrm{RP})+25 \% \mathrm{P}(\mathrm{SSP})$.

At flowering the PSB population increased in the order $100 \% \mathrm{SSP}, 75 \% \mathrm{RP}+25 \% \mathrm{SSP}$, $50 \% \mathrm{RP}+50 \% \mathrm{SSP}, 25 \% \mathrm{RP}+75 \% \mathrm{SSP}$, $100 \% \mathrm{P}(\mathrm{SSP})+$ Lime $0.2 \mathrm{LR}$.

At pod formation the trend was $100 \%$ SSP < $75 \% \mathrm{RP}+25 \% \mathrm{SSP}<50 \% \mathrm{RP}+50 \%$ $\mathrm{SSP}<25 \% \mathrm{RP}+75 \% \quad \mathrm{SSP}<100 \% \mathrm{P}(\mathrm{RP})<$ $100 \% \mathrm{P}(\mathrm{SSP})+$ Lime@0.2LR.. At groundnut harvest the trend was $100 \% \quad \mathrm{RP}<100 \%$ $\mathrm{P}(\mathrm{SSP})<50 \% \mathrm{RP}+50 \% \mathrm{SSP}<25 \% \mathrm{P}(\mathrm{RP})+$ $75 \% \mathrm{P}(\mathrm{SSP})<75 \% \mathrm{P}(\mathrm{RP})+25 \% \mathrm{P}(\mathrm{SSP})<100 \%$ P(SSP)+Lime@0.2LR.

Total biomass production $\left(\mathrm{t} \mathrm{ha}^{-1}\right)$ in the cropping sequence as affected by different P-sources

The total biomass production in maize which ranged from 5.59-11.15 $\mathrm{t} \mathrm{ha}^{-1}$ with the treatment control and 100\% P (SSP)+Lime@ 0.2 LR respectively. The highest biomass yield was produced by the treatment received 100\% P (SSP) +Lime@ 0.2 LR (11.15 t ha ${ }^{-1}$ ). 


\section{Crop Information and Inputs}

\begin{tabular}{|c|c|c|}
\hline Test Crop & Maize & Groundnut \\
\hline Variety & PAC-752 & TAG-24 \\
\hline Duration & 120 days & 120 days \\
\hline Season & Kharif & Rabi \\
\hline $\begin{array}{c}\text { Fertilizer dose } \\
\left(\mathbf{N}-\mathbf{P}_{2} \mathrm{O}_{5}-\mathbf{K}_{2} \mathbf{O}\right) \mathrm{kg} / \mathrm{ha}\end{array}$ & $150-50-50$ & $20-40-40$ \\
\hline Lime & @ 0.2 L.R & @ 0.2 L.R \\
\hline
\end{tabular}

Total Heterotrophic Bacteria (c.f.u. X $10^{4} \mathrm{~g}^{-1}$ soil) at different growth stages of Groundnut crop treated with various $P$ sources

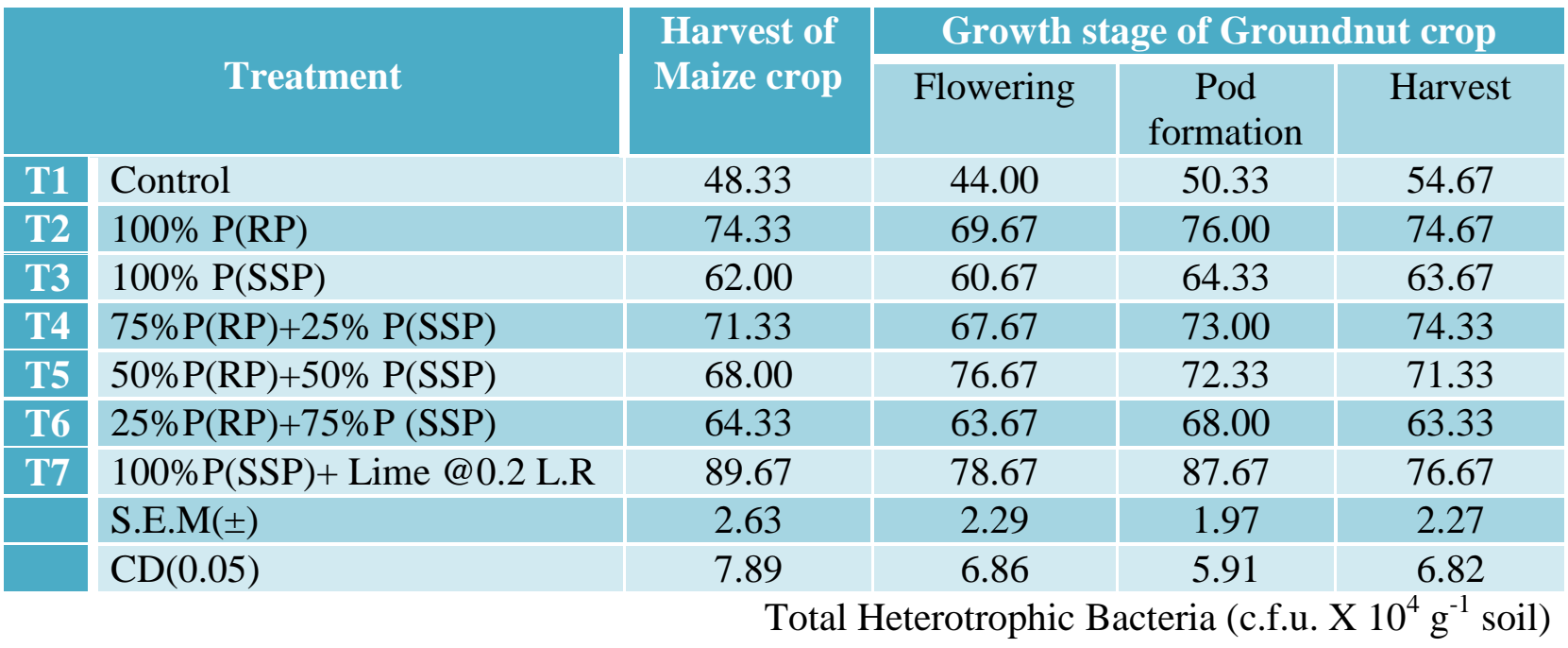

Phosphorous solubilising bacteria (PSB) (c.f.u. $X 10^{4} \mathrm{~g}^{-1}$ soil) at different growth stages Groundnut crop treated with various $P$ sources

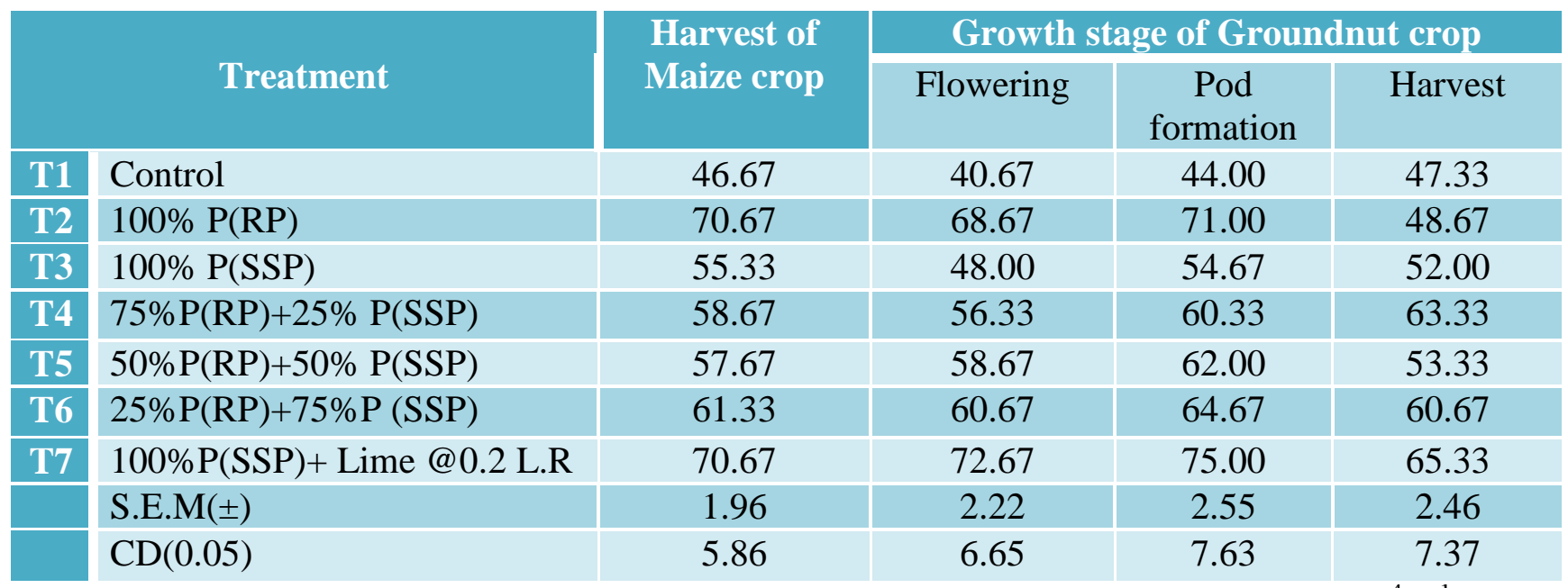

Phosphorous solubilising bacteria (PSB) (c.f.u. X $10^{4} \mathrm{~g}^{-1}$ soil) 
Total biomass production $\left(\mathrm{t} \mathrm{ha}^{-1}\right)$ in the cropping sequence as affected by different P-sources

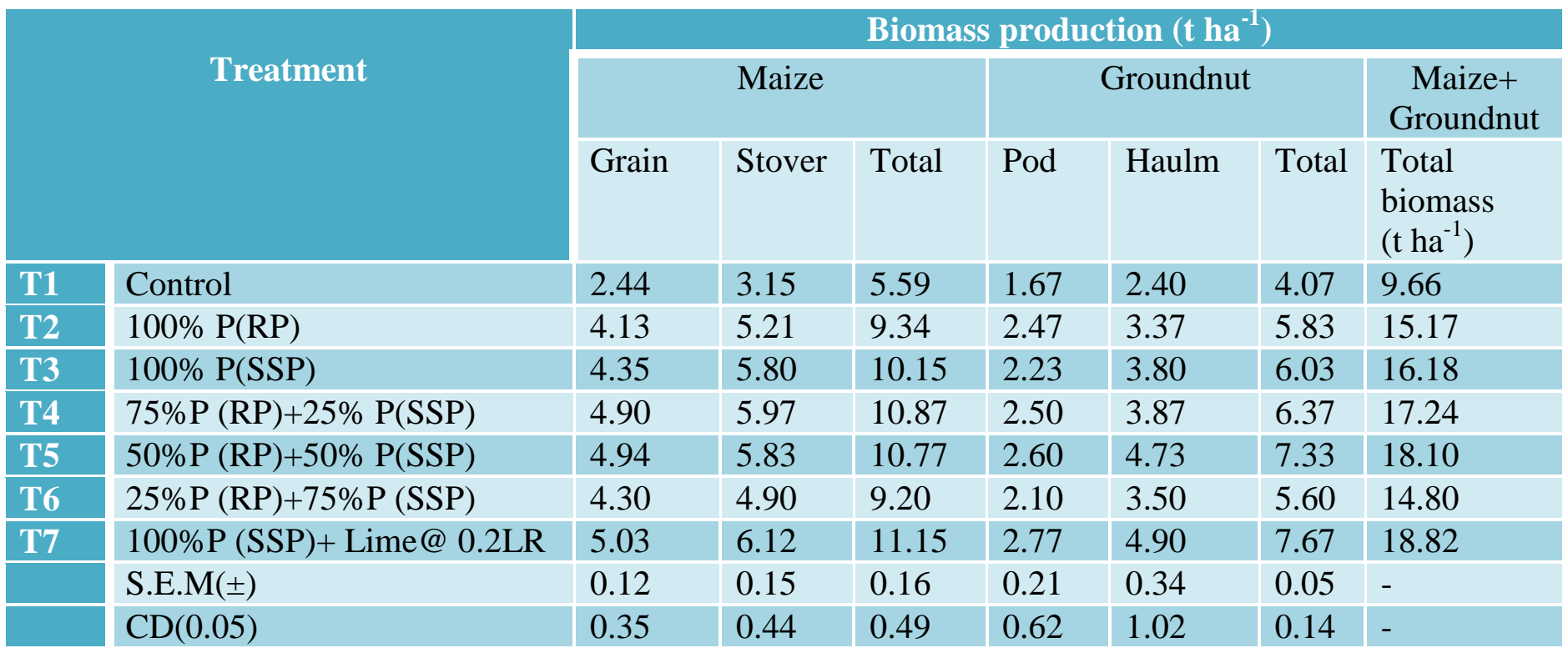

The same trend was observed in total biomass production in groundnut which ranged from $4.07-7.67 \mathrm{t} \mathrm{ha}^{-1}$ the total biomass produced by cropping system ranged from 9.66-18.82 (t $\mathrm{ha}^{-1}$ ) with control and $100 \%$ P (SSP) +Lime@ 0.2 LR. The treatment received $50 \%$ (RP) $+50 \%$ SSP followed the $2^{\text {nd }}$ highest.

The treatment 100\%P (SSP) +Lime @ 0.2LR also recorded the highest yield, Biomass production, available Total Heterotrophic Bacteria population and Phosphorous solubilising bacteria population occurred as compared to other treatments.

\section{Acknowledgement}

The authors are thankful to the support of the Professor G.H. Santra in Department of Soil Science and Agricultural Chemistry, College of Agriculture, OUAT, Bhubaneswar, to conduct the field experiment in the Central Farm, OUAT of the Department and providing the necessary facilities and financial support to carry out the work smoothly.

\section{Abbreviations}

P-Phosphorous

RP-Low grade Rock phosphate

SSP-Single super phosphate

LR-Lime requirement

c.f.u.-Colony Forming Unit

\section{References}

Ahemad M., Khan M.S, Effect of fungicides on plant growth promoting activities of phosphate solubilizing Pseudomonas putida isolated from mustard (Brassica campestris) rhizosphere, Chemosphere 86:945-950, 2012.

Ahemad M., Zaidi A., Khan M.S and Oves $\mathrm{M}$, Biological importance of phosphorus and phosphate solubilizing microorganisms - an overview, In: Khan MS, Zaidi A (eds) Phosphate solubilizing microbes for crop improvement. Nova, New York, pp 1-4, 2009.

Dametario $\mathbf{J}$ L, Ellis $\mathbf{R} \mathbf{J}$ and Paulsen G M, Nodulation and Nitrogen Fixation by 
two soybean varieties as affected by phosphorus and zinc nutrition. Agronomy Journal 64, 566-571, 1972.

Kannapiran. E and Sri Ramkumar V, Isolation of phosphate Solubilizing bacteria from sediments of Thondi coast, Palk Strait, Southeast coast of India. Annals of Biological Research.25:157-163.2011

Khan M.S., Zaidi A., Wani P.A., Ahemad M and Oves M, Functional diversity among plant growth-promoting rhizobacteria, In: Khan MS, Zaidi A, Musarrat J (eds) Microbial strategies for crop improvement. Springer, Berlin, pp 105-132 2009.

Khan MS., Ahmad E., Zaidi A and Oves M, Functional aspect of phosphatesolubilizing bacteria: importance in crop production, In: Maheshwari DK et al., (eds) Bacteria in agro biology: crop productivity. Springer, Berlin, pp 237 2652013.

Mengel K., and Kirkby E. A., Principles of plant nutrition, international Potash Institute, P.O. Box, C+ 1-3048, Worbau Fen, Bern/Switzerland 1987.

Mishra U. K., and Pattanayak S. K., Characterization of rocks phosphates for direct use of different cropping sequences. Technical Report of the USIndia Fund project Number: In -AES-
708, Grant Number FG-In -744. 19911997.

Rodríguez H, Fraga R. Phosphate solubilizing bacteria and their role in plant growth promotion. Biotechnology Adv.; 17:319-339, 1999.

Sanjotha G and Sudheer Manawadi, Isolation, Screening and Characterization of Phosphate Solubilizing Bacteria from Karwar Costal Region, International Journal of Research Studies in Microbiology and Biotechnology (IJRSMB) Volume 2, PP 1-6, 2016

Shenoy V.V and Kalagudi G.M, Enhancing plant phosphorus use efficiency for sustainable cropping, Biotechnology Adv 23:501-513, 2005.

Somaya SirElkhatim Mohamed and Ammar Salama Abdalla, Growth and Yield Response of Groundnut (Arachis hypogaea L.) to Microbial and Phosphorus Fertilizers, Journal of AgriFood and Applied Sciences, Vol. 1(3), pp. 78-85, 2013.

Wang X., Wang Y., Tian J., Lim BL., Yan X. and Liao $\mathrm{H}$, over expressing At PAP15 enhances phosphorus efficiency in soybean, Plant Physiology 151:233240, 2009.

\section{How to cite this article:}

Suraj Mali, G.H. Santra, Tupaki Lokya and Jaya Prajapati. 2018. Microbial Diversity in Various Combinations of Phosphorous Sources in Maize-Groundnut Cropping Sequence in an Alfisols of Odisha, India. Int.J.Curr.Microbiol.App.Sci. 7(02): 3477-3482.

doi: https://doi.org/10.20546/ijcmas.2018.702.414 